\title{
Teachers' Awareness and Improvisation Skills of Scientific Visual Resources as Determinant Of Pupils Learning Outcomes in Basic Science and Technology
}

\author{
${ }^{1}$ IsholaAkindele Salami, ${ }^{2}$ Monisola Onikepo Olotu \\ ${ }^{I}$ Early Childhood Education Unit Department of Teacher Education University of Ibadan
}

\begin{abstract}
The proper use of learning resources makes teaching lively, more involving for the learners and long lasting experience. The quality of any scientific skill acquisition by pupils is determined by the qualities of the teachers' level of awareness and their improvisation skills. It is against this that the study seeks to examine teachers' awareness and improvisation skills of scientific visual resources as a determinant to pupils learning outcomes in basic science and technology. Ex-post facto type of the causal comparative research design was adopted. 55 basic science and technology teachers and 550 pupils were involved in the study. Two instruments were used to collect data for this study; Teachers' Awareness and Improvisation Skills Questionnaire (0.69) and Pupils Achievement Test in Basic Science and Technology (0.7). Data collected were analysed using mean, standard deviation, percentage and multiple regressions. The result indicated that teachers' awareness on ways of improvisation was average $[\bar{X}=2.83(56.6 \%)]$ and their improvisation skills was very low $[\bar{X}=4.25$; (10.6\%)]. Pupils' achievement in Basic Science and Technology was average [ $\bar{X}=8.07 ;(53.8 \%)]$. There existed no significant joint influence of teachers' awareness and improvisation skills of scientific visual resources on pupils' attitude to Basic Science and Technology $\quad\left(F_{(2,52)}=1.583 ; \mathrm{P}>0.05\right)$ and also in pupils' academic achievement in basic science and technology $\left(F_{(2,52)}=0.015 ; p>0.05\right)$. It is recommended that primary school teachers should make effort to acquire more knowledge on various ways by which scientific visual resources could be improvised.
\end{abstract}

Key words: Resources improvisation, awareness, scientific skills, learning outcomes.

\section{Introduction}

Universally, the starting point of any academic journey is the primary education. This level of education is the foundation on which every other academic pursuit is laid. Once a thorough foundation is laid at this level, to build on it becomes an easy task. Primary education is the education given to the children within the ages of six to eleven years in a school environment. It is very important in that it is the stage where permanent literacy and numeracy are inculcated into the children. This elementary education as the bedrock of our educational continuum therefore requires a solid foundation. This level of education is also a gateway to all higher levels of education that train scientist, teachers, doctors and other highly skilled professionals. This level of education, according to Njoku (2000), is regarded as very vital and foundational to all types of education any person can receive in life. Supporting this, Osinubi (2004) said that a firm foundation at the primary level is pivotal to a robust educational system

The National Policy on Education (2004) states one of the objectives of primary education as the laying of a sound basis for scientific and reflective thinking. This is based on the Federal Government of Nigeria's adoption of science education as an instrument par excellence of national development (Ogunkola, 2000). Thus, many subjects are been taught at the primary level of which basic science and technology is one of the core subjects. Almost all young children in almost all environments 'do science' and they engage in scientific thinking, constructing a framework of relationship within which factual information can be organized into meaningful and useful concept (Brewer 2007). Ogunleye (2000) defined science as that human activity concerned with the understanding of our world. Science is also regarded as the cornerstone of technological and development of any nation. To achieve the objective of laying a sound basis for scientific and reflective thinking, the teaching of science especially at this elementary level must be given greater attention.

Kolawole (1999) explained that one of the earliest traits shown by a child is his manipulative skills and that he should be exposed to handling many objects in the environment. This is an implication that any effective teaching or dissemination of knowledge has to rest effectively on a foundation of adequate resources which is very important when it comes to teaching children and when the subject is science. In spite of all the efforts to make science education effective, there has been poor performance of students in science at the secondary school final examination which have consequently led to the low enrolment in tertiary level of education in science related courses (Okoronka, 2004). This poor performance has been traced to the poor science teaching 
and learning pupils are exposed to at the primary level which is to serve as the basic foundation. This lack of interest in secondary school students and undergraduates has generated much concern about the teaching learning processes of science especially at the foundation level which is the primary level (Balogun, 2000).

Popoola (2002) believed that the problem of science education can be traced to the poor teaching methods of the teachers. This is in support of Eze (1991) in the word of a layman's language that 'like the teacher, so the taught'. This is an implication that no learning could be better than its teaching. The role of teachers has evident significance. While searching for causes of the poor performance of students, Igwe (2002) noted that the traditional ways of teaching in the classroom, which is mainly teacher- centred, chalk and talk, is no longer satisfactory in our technologically advancing world. Akinola (2006) was of the opinion that students failed science because of teachers' methodology and the structuring of the curriculum and that science teaching is not taken serious in many of our primary schools which makes a class teacher who is not a trained science teacher to be teaching science. He disregarded the idea of social study graduate teaching elementary science in primary schools and concluded that he would end up destroying the scientific ability of the child.

Therefore in the new approach to teaching science in the primary schools, the aim is not to pour in facts and to rely on textbooks but rather to construct an environments of materials in which a child can explore for himself by feeling, comparing, discovering relationship through his own observation. The effective teaching of science concept therefore requires effective communication techniques since science consist not ordinarily impacting the facts but encouraging the students to observe and reason. For this effective communication to take place in the science classes, researchers suggested the use of interactive approach to science teaching with audio, visual and audiovisual materials to stimulate students' interest and improve their academic achievements. Esu et al. (2004) assert that these instructional materials are the pivot on which the wheel of the teachinglearning process rotates. . They help to promote greater acquisition and higher retention of factual knowledge as well as contribute to the development of attitudes and behaviour change. They challenge pupils' creativity and help to overcome physical disabilities and hindrances to learning in the subject matter. . Instructional materials which include audio, visuals and audio visual materials (Igwe 2005) could be the potential materials that would bring about better instruction in pre-primary / primary science in lower and middle level schools in Nigeria.

Uzoegwu (2001) agreed that these materials enhance learning by making acquisition, retention and recall easy. When these materials are effectively used, students have the privilege of multiple learning and gain wide range of experience while teaching becomes easier and enjoyable to the teacher. Today, science teachers make use of science laboratories with standard science equipment. Improvisation and substitution of instructional materials are encouraged where original is absent or inadequate. Besides, it makes science teaching more meaningful and real when Local Materials are used for instructional purposes (Olasehinde (2004). The role of primary school teachers is to make materials available to teach science adequately. Due to some problems of assess to materials, the primary school teachers can resolve to improvise or manipulate the use of locally gotten materials as the essential resources for his teaching. Omosanya et al (2008) noted that improvisation demands adventure, creativity, curiosity and perseverance on the part of the teacher. The author added that such skills are only realised through well planned training programme on improvisation. In view of this, Okafor (2000) opined that only the highly creative, resourceful, committed and dedicated teachers can resort to acquiring and improvising scarce resources.

Improvisation in science teaching, as defined by Oke (2006) is the art of using alternative materials and resources locally available; to facilitate teaching whenever there is lack or shortage of specific first- hand teaching aids or equipment. Rightly conceived, it means substituting something in place of another to serve a unique function. Hence, improvisation here could be viewed as a creative response by the teacher to specific needs and challenges of the actual teaching situation. Eyetsemitan (2000) is of the opinion that improvisation gives new concept of things outside the range of ordinary experiences to the learners and makes learning last longer in them. With respect to science education at the primary school level, the learning experience is intended to be "pupil-centred" and based upon practical activities. Children should learn through their eyes, ears, and as well as with their hands.

In view of the decreasing interest in science subjects, it has become necessary to look for a more interesting and effective ways of teaching the subject. It is therefore considered imperative to study the impact of teacher's awareness and improvisation skills of scientific visual materials on primary school pupils' learning outcomes in basic science and technology.

\section{Research Questions}

1. To what extent are primary school teachers aware of various ways by which scientific visual resources could be improvised?

2. What is the extent of improvisation skills of scientific visual resources of the primary school teacher?

3. What is the performance of primary $\mathrm{V}$ pupils in basic science and technology? 


\section{Hypothesis}

H01 There is no significant joint influence of teachers' awareness and improvisation skills on pupils' attitude to basic science and technology

H02 There is no significant joint influence of teachers' awareness and Improvisation skills on pupils' academic achievement in basic science and technology

\section{Methodology}

The study used ex-post facto type of the causal comparative research design. The study involves investigation of relationship among variables in order to determine cause-effect relationship where the independent variables will not be manipulated. The independent variables are teachers' awareness of scientific visual resources and teachers' improvisation skills of scientific visual resources while the dependent variables are pupils' achievement in basic science and technology and pupils' attitude towards science.

The target population involved the primary five pupils and their respective primary four basic science and technology teachers in103 public primary schools in Ondo-West and Ondo -East local government area. A simple random sampling was used to select 50 schools for this study. A systematic random sampling was used in selecting ten pupils from each arm of the class using the first ten even numbers of the class register. All the primary five arms in the selected schools with more than one arm were used for this study. Their respective primary four Basic Science and Technology teachers were automatically selected. The sample consisted of two local governments, fifty primary schools, 550 primary five pupils and 55 Basic Science and Technology teachers.

The instrument used to collect data for this study was Teachers' Awareness and Improvisation Skills Questionnaire (TAISQ) and Pupils Achievement Test in Basic Science and Technology (PATBST). The instruments were designed by the researcher. The TAISQ was divided into four sections. The first section was designed to obtain the personal information of teachers like the name of school, gender, years of experience, qualification and area of specialisation. Section B which contained ten items was developed to obtain the extent of teachers' awareness of improvisation of scientific visual resources. Section $\mathrm{C}$ was designed to find out the extent of teachers awareness of various materials for improvisation of readymade scientific visual resources and it contained ten items. Section D which contained five items was mainly designed to determine the teachers' improvisation skills of scientific visual resources. The PATBST was divided into two sections. Section A is the achievement test on basic science and technology which contained fifteen items. Section B which contained ten items was designed to obtain information on pupils' attitude to basic science and technology.

A reliability test was conducted on the teachers' awareness and improvisation skills questionnaire using Cronbach Alpha technique at 0.69 co-efficient while the reliability co-efficient of the pupils achievement test on basic science and technology was 0.7 using Kurder Richardson formula 20. The reliability test of the pupils' attitude towards science was conducted using Split Half method at a co-efficient of 0.68. In analysing the data collected, percentage, mean, and standard deviation are the descriptive statistics used to analyse the demographic data as well as to answer the research questions. Multiple regressions was used to test the hypotheses at 0.05 level of significance.

\section{Findings and Comments}

Research question 1: To what extent are primary school teachers aware of various ways by which scientific visual resources could be improvised?

Table 1: Extent of Primary School Teachers' Awareness on Various Ways of Improvising Scientific

\begin{tabular}{|c|c|c|c|c|c|c|c|c|}
\hline$s / n$ & Statement & N.A & L.A & $\mathbf{A}$ & M.A & V.M & $\mathbf{M}$ & SD \\
\hline 1 & $\begin{array}{l}\text { Scale for measuring mass can be } \\
\text { improvised using two sticks }\end{array}$ & $\begin{array}{l}- \\
(0.0)\end{array}$ & $\begin{array}{l}\mathrm{I} 7 \\
(30.9)\end{array}$ & $\begin{array}{l}20 \\
(36.4)\end{array}$ & $\begin{array}{l}11 \\
(20.0)\end{array}$ & $\begin{array}{l}7 \\
(12.7)\end{array}$ & 3.15 & 1.00 \\
\hline 2 & $\begin{array}{l}\text { Measuring cylinder can be produced } \\
\text { locally }\end{array}$ & - & $\begin{array}{l}4 \\
(7.3)\end{array}$ & $\begin{array}{l}22 \\
(40.0)\end{array}$ & $\begin{array}{l}18 \\
(32.7)\end{array}$ & $\begin{array}{l}11 \\
(20.0)\end{array}$ & 3.65 & 0.89 \\
\hline 3 & $\begin{array}{l}\text { Discarded insecticides can be used to } \\
\text { locally produce concave-convex mirror }\end{array}$ & $\begin{array}{l}29 \\
(52.7)\end{array}$ & $\begin{array}{l}20 \\
(36.4)\end{array}$ & $\begin{array}{l}4 \\
(7.3)\end{array}$ & $\begin{array}{l}1 \\
(1.8)\end{array}$ & $\begin{array}{l}1 \\
(1.8)\end{array}$ & 1.64 & 0.85 \\
\hline 4 & $\begin{array}{l}\text { Stove can be used instead of Bunsen } \\
\text { burner }\end{array}$ & $6 \quad(10.9)$ & - $\quad(0.0)$ & $16(29.1)$ & $16(29.1)$ & $27(49.1)$ & 4.05 & 1.27 \\
\hline 5 & $\begin{array}{l}\text { Nail can be used to locally produce } \\
\text { temporary magnet }\end{array}$ & $\begin{array}{l}32 \\
(58.2)\end{array}$ & $\begin{array}{l}6 \\
(10.9)\end{array}$ & $\begin{array}{l}7 \\
(12.7\end{array}$ & $\begin{array}{l}2 \\
(3.6)\end{array}$ & $\begin{array}{l}8 \\
(14.5)\end{array}$ & 2.05 & 1.48 \\
\hline 6 & $\begin{array}{l}\text { A used light bulb can be improvised for } \\
\text { a round bottom flask }\end{array}$ & $\begin{array}{l}28 \\
(50.9)\end{array}$ & $\begin{array}{l}13 \\
(23.6)\end{array}$ & $\begin{array}{l}4 \\
(7.3)\end{array}$ & $\begin{array}{l}4 \\
(7.3)\end{array}$ & $\begin{array}{l}6 \\
(10.9)\end{array}$ & 2.04 & 1.37 \\
\hline 7 & $\begin{array}{l}\text { A dissecting needle can be improvised } \\
\text { using common items }\end{array}$ & $\begin{array}{l}8 \\
(14.5)\end{array}$ & $\begin{array}{l}14 \\
(25.5)\end{array}$ & $\begin{array}{l}27 \\
(49.1)\end{array}$ & $\begin{array}{l}4 \\
(7.3)\end{array}$ & $\begin{array}{l}2 \\
(3.6)\end{array}$ & 2.60 & 0.95 \\
\hline 8 & $\begin{array}{l}\text { Beakers and funnel can be made locally } \\
\text { using plastic bottles }\end{array}$ & $\begin{array}{l}1 \\
(1.8)\end{array}$ & $\begin{array}{l}3 \\
(5.5)\end{array}$ & $\begin{array}{l}11 \\
(20.0)\end{array}$ & $\begin{array}{l}13 \\
(23.6)\end{array}$ & $\begin{array}{l}27 \\
(49.1)\end{array}$ & 4.13 & 1.04 \\
\hline
\end{tabular}


Teachers’'Awarness And Improvisation Skills Of Scientific Visual Resources As Determinant Of

\begin{tabular}{|c|c|c|c|c|c|c|c|c|}
\hline 9 & $\begin{array}{l}\text { An overflowing can (eureka) can be } \\
\text { improvised where the readymade is not } \\
\text { available }\end{array}$ & $\begin{array}{l}24 \\
(43.6)\end{array}$ & $\begin{array}{l}15 \\
(27.3)\end{array}$ & $\begin{array}{l}7 \\
(12.7)\end{array}$ & $\begin{array}{l}3 \\
(5.5)\end{array}$ & $\begin{array}{l}6 \\
(10.9)\end{array}$ & 2.13 & 1.33 \\
\hline 10 & $\begin{array}{l}\text { A tripod stand can be improvised using } \\
\text { a large cylindrical beverages tin }\end{array}$ & $\begin{array}{l}7 \\
(12.7)\end{array}$ & $\begin{array}{l}12 \\
(21.80\end{array}$ & $\begin{array}{l}21 \\
(38.20\end{array}$ & $\begin{array}{l}5 \\
(9.1)\end{array}$ & $\begin{array}{l}10 \\
(18.2)\end{array}$ & 2.98 & 1.25 \\
\hline
\end{tabular}

Aware

Table 1 shows the extent of primary school teachers' awareness of various ways by which scientific visual resources could be improvised. The table shows that some teachers had much awareness that measuring cylinder can be improvised locally $(\bar{X}=3.65)$, that stove can be used instead of Bunsen burner $(\bar{X}=4.05)$ and that beakers and funnels can be made locally using plastic bottles $(\overline{\mathrm{X}}=4.13)$. The table also shows that some teachers are aware that scale for measuring mass can be improvised using two sticks $((\bar{X}=3.15)$, that dissecting needle can be improvised using common items $(\overline{\mathrm{X}}=2.60)$ and that a tripod stand can be improvised using a large cylindrical beverage $\operatorname{tin}(\overline{\mathrm{X}}=2.98)$. Again, the table shows that teacher are less aware that a discarded insecticide can be used to locally produce concave -convex mirror $(\overline{\mathrm{X}}=1.64)$, that nail can be used locally to produce temporary magnet in the classroom $\quad(\bar{X}=2.06)$, that a used light bulb can be improvised for a round bottom flask $(\overline{\mathrm{X}}=2.04)$ and that an overflowing can (eureka) can be improvised where the readymade is not available $(\overline{\mathrm{X}}=1.13)$.

However, the weighted average is 2.83 , which could be rated to $(56.6 \%)$. This implied that the extent of teachers' awareness on ways of improvising scientific visual resources was average. The finding revealed that some of the teachers exhibited less awareness of some resources. The findings could be as a result of the fact that most Basic Science and Technology textbooks on which teachers depended include a portion of teachers' activities where materials for teaching are stated. It could also be that many of them were taught while in training colleges and were well aware of some common items locally gotten which can be manipulated to serve dual purposes even in the teaching of Basic Science and Technology. This finding disagrees with the finding from a study by Regina et al (2009) on Teachers' Awareness and Utilization of Innovative Teaching Strategies in Secondary School Science. In the study, it was discovered that the extent of awareness of science teachers on the innovative teaching strategies was high.

Research Question 2: What is the extent of improvisation skills of scientific visual resources of the primary school teacher?

Table 2: Extent of Teachers' Improvisation Skills

\begin{tabular}{lllll}
\hline Score & $\begin{array}{l}\text { Percentage } \\
\text { aggregate }\end{array}$ & Frequency & Percentage & $\begin{array}{l}\text { Mean } \\
\begin{array}{l}\text { Standard } \\
\text { deviation }\end{array}\end{array}$ \\
\hline $\mathbf{0}-\mathbf{1 6}$ & $0-39 \%$ & 49 & 89.1 & 4.2 \\
$\mathbf{1 7}-\mathbf{1 9}$ & $40-49 \%$ & 0 & 0.0 & $(10.6 \%)$ \\
$\mathbf{2 0}-\mathbf{2 4}$ & $50-59 \%$ & 5 & 9.1 & \\
$\mathbf{2 5}-\mathbf{2 8}$ & $60-69 \%$ & 0 & 0.0 & 1.8 \\
$\mathbf{2 9}$ and above & $70 \%$ and above & 1 & & \\
Total $=\mathbf{5 5}$ & & & & \\
\hline
\end{tabular}

Table 2 shows the extent of teachers' improvisation skills of scientific visual resources. It shows that $89.1 \%$ scored between 0 and 16; 9.1\% scored between 20 and 24 and the remaining $1.8 \%$ scored above 29 . As can be seen from the table, the mean score of teachers' improvisation skills was 4.26 which was rated to $10.6 \%$. Thus, it can be concluded that the extent of primary school teachers' improvisation skills was very low.

This finding therefore could be as a result of the fact that most of the primary school teachers who teach basic science and technology did not have their specialisation in science based courses and since they did not specialise in sciences, they could only manage to do all they know. On the other hand, the teachers whose area of specialisation is science based were not well equipped in skills of improvisation of scientific visual resources. This could be as a result of laziness on the part of the teachers and inability to update their knowledge with new ideas in the field. This could also be because Teachers often depended so much on the use of readymade resources and do resort to merely teach instead of improvising in a case where readymade materials were not available. In addition to this, their average extent of awareness could affect their improvisation skills of the resources. On this finding, Maduabunm (2003) had reported lack of adequate professional training as a major problem militating against the effective use local resources for science teaching. Akinsola (2000) also considered the human factors as the teachers' professional commitment, creativity, mechanical skills, initiative and resourcefulness and that many Nigerian science teachers exhibited poor attitude towards improvisation. 
Research Question 3:What is the performance of primary five pupils in Basic Science and Technology?

Table 3: Average Performance of Pupils in Basic Science and Technology

\begin{tabular}{llllll}
\hline Score & $\begin{array}{l}\text { Percentage } \\
\text { aggregate }\end{array}$ & Frequency & Percentage & Mean & $\begin{array}{c}\text { Standard } \\
\text { deviation }\end{array}$ \\
\hline $\mathbf{0 - 5}$ & $0-39 \%$ & 80 & 14.6 & 8.09 & 2.58 \\
$\mathbf{6 - 7}$ & $40-49 \%$ & 150 & 27.3 & $(53.8 \%)$ & \\
$\mathbf{8 - 9}$ & $50-59 \%$ & 165 & 30.0 & & \\
$\mathbf{1 0}-\mathbf{1 1}$ & $60-69 \%$ & 104 & 18.9 & & \\
$\mathbf{1 2}$ and above & 70 and above & 51 & 9.3 & & \\
Total = 550 & & & & & \\
\hline
\end{tabular}

Table 3 shows the average performance of pupils in basic science and technology. The table showed that the mean score of the pupil's performance is 8.07 which can be rated to $53.8 \%$. Based on this, it can be concluded that the performance of the pupils is average. This average performance could be as result of the fact that most of the teachers who taught them were not trained to teach science and this would make the teacher to teach what they know and leave the aspects they did not know untouched. Also, it could be that the students were often taught in abstract what they could have been taught using practical approach. The average awareness and very low improvisation skills of this Basic Science and Technology could also be a reason for the pupils' average performance. Supporting this, Akinola (2006) in another finding was of the opinion that students failed science because of teachers' methodology and the structuring of the curriculum and that science teaching was not taken serious in many of our primary schools which made a class teacher who was not a trained science teacher to be teaching science.

\section{Testing the Hypotheses}

H01:There is no significant joint influence of teachers' awareness and improvisation skills on pupils' attitude to basic science and technology

Table 4: Summary of Multiple Regression Showing Joint Influence of Teachers' Awareness and Improvisation Skills on Pupils' Attitude to Basic Science and Technology.

\begin{tabular}{|l|l|l|l|l|l|l|}
\hline Model & Sum of Squares & Df & Mean Square & F & Sig & Remark \\
\hline Regression & 4.346 & 2 & 2.173 & 1.583 & .215 & N.S \\
\cline { 1 - 4 } Residual & 71.364 & 52 & 1.372 & & & \\
\cline { 1 - 4 } & 75.709 & 54 & & & & \\
\hline
\end{tabular}

$\mathrm{R}=.240 ; \mathrm{R}$ Square = .057; Adjusted R square $=.021$; (Dependent variable: pupils' attitude to Basic Science and Technology)

Table 4 shows that the co-efficient of determinant (adjusted $\mathrm{R}$ square $=.021$ ) indicate that the joint influence of teachers' awareness and improvisation skills accounted for $2.1 \%$ variance in pupils' attitude to basic science and technology (Adjusted R square X100 =2.1). This joint influence is not significant on pupils' attitude to basic science and technology. $(\mathrm{F}(2,52)=1.583 ; \mathrm{P}>0.05)$. Hence, the hypothesis was not rejected. This finding could be as a result of the very low improvisation skills of the teachers. It could also be as a result of the pupils' perception of the subject as one to be read and understood and not as an enquiry based or activity oriented subject. Igwe (2002) in his finding submitted that for teaching and learning of science to be interesting and stimulating, there has to be motivation on the part of both the teacher and the learner so as to ensure the development of positive attitude and subsequently maximum academic achievement. From previous findings, it had been observed that teachers taught science in a way that merely requires the pupils to listen, read and regurgitate and that this depicted negative attitude to teaching and pupils' attitude to science.

H02: There is no significant joint influence of teachers' awareness and Improvisation skills on pupils' academic achievement in basic science and technology 
Table 5: Summary of Multiple Regression Showing Joint Influence of Teachers' Awareness and Improvisation Skills on Pupils' Academic Achievement in Basic Science and Technology

\begin{tabular}{|l|l|l|l|r|l|l|}
\hline Model & Sum of Squares & Df & Mean Square & F & Sig & Remark \\
\hline Regression & 4.119 & 2 & 2.059 & .015 & .985 & N.S \\
\cline { 1 - 4 } Residual & 7118.681 & 52 & 136.898 & & & \\
\cline { 1 - 3 } Total & 7122.800 & 54 & & & & \\
\hline
\end{tabular}

$\mathrm{R}=.024 ; \mathrm{R}$ Square $=.001 ;$ Adjusted R square $=.038$ (Dependent variable: Pupils' academic achievement)

Table 5 shows that the co-efficient of determinant (adjusted $\mathrm{R}$ square $=.038$ ) indicate that the joint influence of teachers' awareness and improvisation skills accounted for $3.8 \%$ variance in pupils' academic achievement in basic science and technology (Adjusted R square X $100=3.8$ ). This joint influence was not significant on pupils' academic achievement in basic science and technology. $(\mathrm{F}(2,52)=.015 ; \mathrm{P}>0.05)$. Hence, the hypothesis was not rejected. This finding could be as a result of the ways in which teachers failed to display understanding of the best methods that could be used to teach the subjects and their very low improvisation skills. . The few basic science and technology teachers who were well skilled in improvisation of scientific visual resources had their pupils performed very well above average in the subject. This could implied that the more a teacher understands the subject, the best way to teach it and materials to enhance learning, the better the achievement of the pupils.

Yara (2009) in a finding discovered that teachers' attitude towards science is a significant predictor of pupils' science achievement as well as their attitude towards science. He found that students' high performance in science could be enhanced by teachers' enthusiasms, resourcefulness and helpful behaviour, teachers' thorough knowledge of the subject matter and their making science quite interesting.

\section{Conclusion}

It was concluded that primary school basic science and technology teachers had an average awareness of ways in which scientific visual resources could be improvised. Their improvisation skills of these scientific visual resources were very low. The academic performance of the pupils in basic science and technology was average. The academic performance of the pupils was not a measure of either the teachers' awareness of ways of improvising scientific visual resources or their improvisation skills of scientific visual resources. The pupils' performance could be high if attention had been paid by the teachers to the knowledge of resources and improvisation skills of scientific visual resources. The versed knowledge of improvisation of scientific visual resource is of paramount importance for any meaningful impact to be made on the learning of sciences by the pupils.

\section{Recommendations}

It is recommended that primary school teachers should make effort to acquire more knowledge on various ways by which scientific visual resources could be improvised where the readymade is not available. This could be done by ensuring that seminars and workshops are frequently attended from time to time. Teachers always should ensure that whatever knowledge acquired at such seminars and workshops should be regularly put into practice to ensure mastery. Teachers are also encouraged to update their knowledge on the use of the internet so as to be getting latest information on science related issues.

Government at all levels should ensure that seminars and workshops are not only organised but should be handled by professionals in science for the basic science and technology teachers in primary schools. During such seminars and workshops, improvisation of common items required for teaching at the primary level, based on the curriculum, should be made practical for easy comprehension. More science trained teachers should also be employed to ensure strict compliance to science specialist teaching basic science and technology in primary schools. In addition, the government should endeavour to build well equipped laboratories in schools which can be a motivator for teachers to build practical works in pupils. Efforts should be made by the zonal offices in charge of teachers posting to ensure that teachers' area of specialisation is taken into consideration in classroom teaching in the regard that science trained teachers are allowed to handle Basic Science and Technology in primary schools so that the foundation of scientific skills can be enhanced in the pupils.

\section{References}

[1] Akinola, B.M.A. (2006). Causes of Mass Failure in senior secondary school Chemistry in Ijebu East Local Government Area of Ogun State.Oro ScienceEducational journal 4.5\&6: 19-28

[2] Akinsola, A.T. (2000). An investigation into the teacher self conceived ability to improvise materials for the teaching of Primary science. International journal on science education 2: 8-12

[3] Balogun, T. A. (2000). Gender issues in the teaching of science technology and mathematics. Perspectives on women in science and technology in Nigeria. Ibadan. Sam Bookman. Educational and Communication Services 47-61 
[4] Brewer, D. (2007).Effects of Inquiry-Based Science Instruction on Science Achievement and Interest in Science: Evidence from Qatar. The Journal of educational Research. 105, Issue 2, 2012

[5] Esu, A., Enukoha, O., Umorem, G., (2004).Curriculum development in Nigeria for colleges and universities.Owerri: Whyte and Whyte Publishers.

[6] Eyetsemitan, P. E. (2000). Improvisation in the teaching of primary science. A paper presented at the $41^{\text {st }}$ annual proceeding of STAN

[7] EzeS.U . (2002). Effect of target task approach on students achievement and

[8] interest in senior secondary school physical chemistry. Unpublished PhD Thesis,

[9] University of Nigeria, Nsukka

[10] Federal Republic of Nigeria (2004): National Policy on Education (Revised), NERC Press,

[11] Lagos

[12] Igwe, I.O. (2002): Relative effects of Framing and Team assisted instructional Strategies on

[13] students' learning outcomes in selected difficult chemistry concepts. Unpublished Ph.D Thesis University of Ibadan, Ibadan

[14] 2005. Education: special methods in science teaching and learning (the conceptual approach). An unpublished mimeograph in science education.Eboyin state university

[15] Kolawole, O. O. (1997). Evaluation of resources for the teaching of science in the primary school in Ibadan north local government area. Unpublished master project, university of Ibadan

[16] Maduabum, M. A. (2003). Teaching Integrated Science Effectively. Onitsha: Space Matrix Publications.25-31

[17] Njoku, Z. C. (2000). Images of females in science: A gender analysis of science and technology activitiesin Nigeria primary science textbooks. Journals of primary education 1(1). 3-12

[18] Ogunkola, B. J. (2000). Instructor expressiveness, student locus of control and cognitive entry behaviour as measure of student' achievement in and attitude towards biology. Unpublished $\mathrm{Ph} . \mathrm{D}$ thesis, Institute of Education, University of Ibadan, Nigeria

[19] Ogunleye, A.O. (2000). Towards the optimal utilisation and management of resources for the effective teaching and learning of physics in schools. Proceeding of the $41^{\text {st }}$ Annual conference of the STAN Sept,2000 215-220 Okafor, P .N. (2000).Laboratory resources and utilisation correlates of chemistry learning outcomes.41 ${ }^{\text {st }}$ Annual conference proceedings of STAN. Nov, 2000: 169-173

[20] Okoronka, A. U. (2004). Model based instructional strategies as determinant of students' learning outcomes in secondary school physics. Unpublished Ph.Dthesis, university of Ibadan.

[21] Olasehinde, O. K. (2005). The availability, teachers awareness and utilization of primary shool environmental science resources at Atiba, oyo east and west local government. An unpublished thesis.University of Ibadan.

[22] Onosanya, S. A. andAdegbija M.V. (2008).Education reform and assessment of teachers' competence in instructional media technology use in junior secondary school in kwara state. An Education reform in Nigeria: Past, present and future.Stirlin-Horden publisher. 259-272

[23] Osinubu, O. (2004). Constructivist method of teaching a meta cognitive strategy as determinant of learning outcomes in primary school science. Unpublished Ph.D thesis in institute of education.

[24] Popoola, A. A. (2002). Effect of heuristic problem solving and programmed instructional strategies on senior secondary school students' learning outcomes in mathematics in Ekiti state, Nigeria.An unpublished thesis.University of Ibadan.

[25] Uzoegwu, P. N. (2001). Availability of instructional materials for effective teaching and learningof English language in the universal basic education scheme.The Nigerian Universal Basic Education Journals 7(1). 12-19 